Brit. J. vener. Dis. (1960), 36, 2.

I.U.V.D.T.*

\title{
REPORT OF THE SECRETARY-GENERAL
}

I have the honour to submit to the General Assembly the report on the activities of the Union, covering the period from the last Assembly held in Stockholm in August, 1957, to the present meeting.

\section{Publications and Technical Activities}

The proceedings of the Conference at Stockholm have been published by the Union, in collaboration with the International Abolitionist Federation and with the financial support of C.I.O.M.S. They have been widely distributed and they represent a very valuable contribution to the study of the medicosocial problem related to prostitution. Some of the papers presented at the Stockholm Conference have been used by the U.N. Secretariat in the compilation of its report on "The suppression of the traffic in persons and the exploitation of prostitution of others" presented to the 12th session of the Social Commission in May, 1959. In the same session a statement on behalf of the Union has been presented by our Regional Office for the Americas.

During the year 1958 a Regional European Conference has been held in Brussels, sponsored jointly by the Union (Regional Office for Europe) and by the Belgian National League against V.D. A report of this meeting and a summary of the papers presented has been published in a special issue of the Bulletin of the Regional Office for Europe. I should like, on this occasion, to associate myself with the feelings of deep regret so well expressed by Dr. Cavaillon on the death of Dr. Gérard, SecretaryGeneral of the Belgian League, who organized so successfully the Brussels meeting and who served for many years as a technical counsellor of the Union with competence, enthusiasm, and devotion.

* Report submitted by Prof. G. A. Canaperia (Via Salaria 237, Rome, Italy) to the General Assembly of the I.U.V.D.T. in London on October 13, 1959.
The death of Dr. Gérard is a great loss for the Union.

An international study group on human trichomoniasis has been recently established as a Union project and the group took a very active part in the organization of the first Canadian symposium on non-gonococcal urethritis, which took place in September, 1959. I wish to express here our gratitude to Dr. Durel for the excellent work he has done in promoting and organizing this study group.

The two bulletins of the Union, the "Bulletin of Information" edited by the Regional Office for Europe and "Novedades" published by the Regional Office for the Americas, were issued regularly. They represent an important voice for the Union's programme and a very valuable link between our organization and its members. I wish to express here my best thanks to our Regional directors, Prof. Hermans and Mrs. Tuller, for their constant and efficient collaboration and for the exceedingly good work they have done for the Union.

\section{CONSUltation AND REPRESENTATION}

A close liaison with the United Nations agencies and other non-governmental organizations working in related fields has been maintained. Our relations with W.H.O. have been extremely good, especially with the section of V.D. and Treponematosis directed by Dr. T. Guthe, to whom I should like to express here my feelings of gratitude for the active and efficient support given to all our activities.

During the past two years the Union has been represented at the following meetings of W.H.O. and U.N. International Children's Fund (UNICEF).

(1) The 11th and 12th World Health Assemblies held respectively in Minneapolis (1958) and Geneva (1959;

(2) The 21st, 22nd, and 23rd sessions of the Executive Board; 
(3) The sessions of the Regional Committee for Europe, held in Monaco (1958) and Bucharest (1959);

(4) The session of the Regional Committee for Americas and the Pan-american Health Conference, held in S. Juan, Puerto Rico (1958);

(5) The sessions of the Regional Committee for the Eastern Mediterranean held in Baghdad (1958) and Alexandria (1959);

(6) The session of the Regional Office for South-East Asia held in New Delhi (1959);

(7) Three meetings of the Executive Board of UNICEF.

I wish especially to mention the active and efficient participation of our Union in the 11th World Health Assembly held at Minneapolis last year to celebrate the tenth Anniversary of WHO, at which Dr. Gurney Clark presented an excellent statement of the problem of veneral disease and treponematosis and of the role of the International Union.

Our organization has also been represented at important meetings of other non-governmental organizations, whose activities are closely related with our own. I refer particularly to the Red Cross Conference at New Delhi (1957) and the International Conference of Social Work in Tokyo (1958).

\section{MEMBERSHIP}

Many efforts have been made in these last 2 years to increase the membership of the Union, and to cultivate and stimulate interest in our work. We have carried out an intensive programme of personal contacts and correspondence with many officials, experts, and organizations, particularly in the Middle East, Far East, Africa, and South America. Some results have been achieved and I am particularly happy to report here that India and Turkey have recently become members of our Union. I am sure that they will make a very valuable contribution to our work. We have good hopes that the negotiations, which are being carried on with certain other countries, including Egypt, Indonesia, Ceylon, Irak, Pakistan, Lebanon, Ethiopia, and Eritrea, may reach a successful conclusion in the near future.

The possibility of establishing other Regional Offices of the Union especially in parts of the world where V.D. and Treponematosis still present a very serious medico-social problem should be explored, but in many countries there is no voluntary organization to provide a nucleus for the establishment of a Regional Office, or if such exists its activities are limited by lack of funds. We are, however, persevering in seeking the means of supplying information and suggestions to interested groups or individuals.

\section{OTHER ACTIVITIES}

In reply to a letter from Senator Humphrey, chairman of a sub-committee for the study of the international health programme of the U.S. Senate, we have provided a report outlining the activities of the Union and the role that it could play in such a programme.

A similar request has been received from C.I.O.M.S. on behalf of UNESCO, and a report on the most important problems and subjects for research in our field of interest has been prepared.

The increasing interest shown by national and international organizations in the problem of coordinating medical research programmes may offer new opportunities for the work of the Union.

The last 12 months have been particularly devoted to the preparations for our London Conference, in close cooperation with the British Federation against the Venereal Diseases. This cooperation has been very harmonious and pleasant and I wish to express here my deep feelings of gratitude to its chairman, Dr. J. A. Scott, O.B.E., to our vicepresident Mr. A. J. King, and particularly to Dr. C. S. Nicol, our technical adviser, who has carried the heavy burden of the organization of this meeting.

I am sure I am expressing your feelings in saying how much we appreciate the perfect arrangements, the good planning, and the charming hospitality we are enjoying in London.

In conclusion, I once more state my belief that the Union can continue to fulfil a very useful function in stimulating and promoting international efforts to control and possibly eradicate venereal diseases and treponematosis throughout the world. To achieve this aim, the Union must count on the interest, support and cooperation of all its members. 